\title{
THE ASSESSMENT OF HEALTH CARE SYSTEM OPERATION EFFICIENCY \\ BASED ON THE EXAMPLE OF POVIATS \\ OF ŁÓDŹ AND WEST POMERANIAN VOIVODSHIPS
}

Danuta Rozpędowska-Matraszek, MSc

Institute of Applied Economics

State Higher Vocational School of Skierniewice

St. Batorego 64C, 96-100 Skierniewice

e-mail:daroma@uni.lodz.pl

Received 22 September 2011, Accepted 2 January 2012

\begin{abstract}
The operation of health care in poviats allows to determine the role of the health care system in the region. The subjects of the analysis are poviats of Łódź and West Pomeranian voivodships characterised by different economic development levels. The analysis uses such tools as agglomerative methods of clustering and econometric models estimated on the basis of panel data. Similar groups of poviats were selected based on their health care system operation levels and econometric analysis was performed concerning factors significantly affecting accessibility of health care in the poviats.
\end{abstract}

Keywords: health care, regional analysis, clustering of poviats, panel models.

JEL classification: $\mathrm{I11}, \mathrm{R} 15, \mathrm{P} 46$. 


\section{Introduction}

Social aspects of regional development are reflected in an improvement in a population's standards of living, social well-being, and quality of life ${ }^{1}$. A special feature of human capital is the health of individuals that form it. Investments in health improve a human's physical and mental condition, which affects the length of life and ability to work ${ }^{2}$.

Pursuant to applicable law, our country's population is provided with universal and equal access to health care. The functioning of health care in poviats allows to determine the role played by the health care system in a region in order to properly supply health care services. It is also the starting point for an analysis presented in this study concerning poviats of Łódź and West Pomeranian voivodships characterised by different development levels.

The main objective of the study is to isolate groups of poviats where health care system functioning conditions are similar and perform an econometric analysis of factors that significantly affect access to health care in poviats of Łódź and West Pomeranian voivodships. The selection of voivodships to be analysed was based on the Community policy resulting from the course of integration processes, regional policy being one of the most important components of those processes.

Regional policy serves to remove regional disproportions, i.e. economic and social differences. Thanks to numerous links with its environment, every territorial unit is an open system, and thus is susceptible to external influences. From the point of view of regional development, it is vital to maintain spatial cohesion in health care. As a result, the development and modernisation of regional infrastructure require, among others, to study changes in health care personnel employment structure and technical infrastructure facilities as elements of that policy. Therefore, verification whether the distribution of poviats in separate voivodships of Poland has a similar impact on the functioning of health care will be presented by using analytical tools of taxonomic and econometric methods. Those methods include, in particular, agglomerative clustering methods and econometric models estimated on the basis of panel data.

\section{Factors Affecting Regional Development}

Based on the assumptions of the general spatial equilibrium theory, the social and economic layout is the system of regions linked with one another through their exchange relations (W. Isard, 1969). Along with economic goods, the system of regions produces and consumes non-economic ones. In a region there are not only entities and individuals operating 
with a view of profit but also social institutions and organisations driven by social motives. Such organisations include the health care system that needs to be properly managed and financed. Being the living space for populations inhabiting them as well as the place of their work and relaxation, territorial units should ensure a good standard of public services by satisfying the needs of their populations, providing them with a sense of security as well as protecting their health and offering social assistance ${ }^{3}$.

At the initial stage of transformation the carried out policy of removing differences led to the economic growth of the biggest cities, with Szczecin being much earlier affected by the policy than Łódź. Diversified spatial structures of those cities were highly adaptable thanks to their well-qualified labour force and higher education institutions. Changes in Poland's international economic relations, and in particular in the geographical structure of its trade turnover with foreign partners, through its links with the EU countries and exchange with those countries, especially with Germany, offer the western regions of Poland more impulses for their development. Diversity is necessary for maintaining competitiveness and desirable if it contributes to innovativeness and increased GDP 4 . Differences in the economic development of the two voivodships situated in different geographical regions of Poland are reflected in the volumes of their GDPs, ${ }^{5}$ being parameters that clearly indicate the extent of regional divergence. Within the space of twelve years considerable GDP volume diversification occurred in those two voivodships. In 1999 the difference was 11,617 million PLN, while in 2010 it increased to 31,166 million PLN (compare Figure 1).

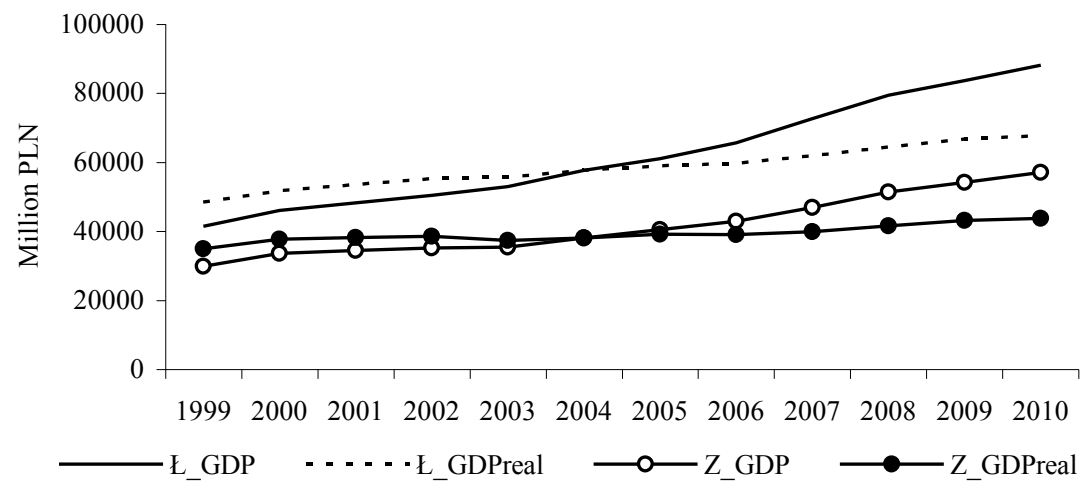

Fig. 1. Comparison of GDPs of Łódź and West Pomeranian voivodships from 1999 to 2010 Source: own calculations based on Central Statistical Office data. 
When comparing shares of GDPs per capita of Łódź and West Pomeranian voivodships in Poland's total GDP per capita in the 1999-2010 period, considerable diversification can also be observed (compare Figure 2).



Fig. 2. Shares of GDPs per capita of selected voivodships in Poland's total GDP per capita from 1999 to 2010

Source: own calculations based on Central Statistical Office data.

Over the period of 12 years fluctuations in the calculated share of Łódź voivodship showed an upward trend from $90.3 \%$ in 1999 to $93.9 \%$ in 2010. Apart from some slight increases, West Pomeranian voivodship maintained a downward trend (10.1 pp.). The analysis of the dynamics of GDP per capita allows to observe its increase throughout the analysed period (compare Figure 3).

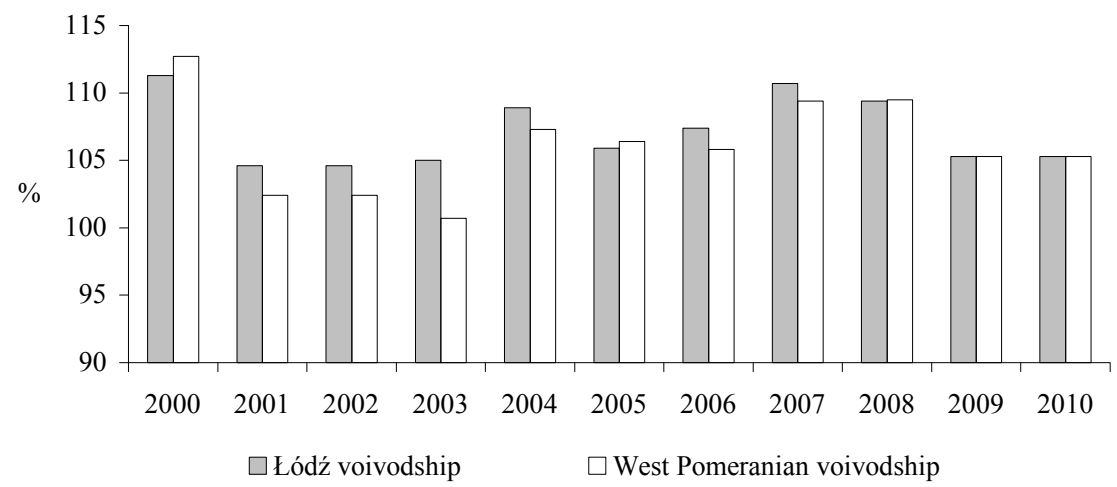

Fig. 3. Dynamics of GDP per capita in selected voivodships from 2000 to 2010

Source: own calculations based on Central Statistical Office data. 
The inflow of financial means from the EU boosted the dynamics from $2004 \mathrm{on}$. Turbulence and a generally difficult situation in the world economy were reflected in a smaller increase in the dynamics from 2009. The geographical location of Łódź voivodship, which is situated in the centre of Poland, is of a key importance for that region and ought to make it an attractive place for investments. The voivodship has become a goods distribution hub for Poland and Europe thanks to major domestic centres of logistics (Stryków and Piotrków Tryb.) As for the location of West Pomeranian voivodship, it borders directly on Germany through its land border, and on Denmark and Sweden through its sea border. Such a location is conducive to emigration for economic reasons and offers considerable tourist potential ${ }^{6}$.

There are medical schools in both the voivodships: the Medical University in Łódź (created through the merger of the Medical Academy and the Military Medical Academy) and the Pomeranian Medical University in Szczecin, which educate medical staff. The biological health condition of our country's population is connected with social changes in the society. The problem of ageing of the society and the demographic structure of the population undergo rapid changes not only due to natural causes but also economic ones. Those changes require thinking about a way to secure the provision of health services and adjust their supply to changing health needs. Transition to the market economy has affected the health care sector too. Since 2004 there has been a substantial increase in the number of non-public hospitals, which has been connected with legislative changes. In 2009 public hospitals in West Pomeranian voivodship accounted for only $4.2 \%$ of their number countrywide and in Łódź voivodship - for 7.2\%. A somewhat bigger share was recorded for non-public hospitals in Łódź voivodship (7.9\%), while for West Pomeranian voivodship it was 3.9\%. Territorial development should take into account local, regional and national potential, and be characterised by a strategic and integrated approach. Development policies ought to consider domestic and European factors ${ }^{7}$.

Despite the Government's consistent and long-term policy, there are still insufficient public funds allocated to the health care sector. That results in differences in the level of meeting health-related needs in specific voivodships. The National Health Fund (until 2003 - the Health Insurance Funds), as the beneficiary of the means, implements the principles of the National Health Policy (NHP) through its activities at the voivodship level and exerts an influence on the processes of medical treatment in specific poviats. The proper management of an Independent Public Health Care Facility leads to an appropriate structure of human resources (in particular the employment of physicians) and material resources (hospitals, outpatient clinics, full-time public assistance facilities). Their efficient use at the level of an individual entity improves the condition of health care at the regional level. 


\section{Description of the Poviats' Population Structure}

One of the features of a region is the size of the population inhabiting its territory which in the case of Łódź voivodship, consists of 24 poviats (including 21 country and 3 municipal ones) and 43 towns and, in the case of West Pomeranian voivodship, is composed of 21 poviats (including 18 country and 3 municipal ones) and 62 towns.

Synthetic population data for the poviats of those two voivodships lead to a conclusion that a majority of the poviats face a decrease in their population size from year to year. There were only three country poviats of West Pomeranian voivodship where the number of inhabitants rose in 2010 as compared with 2009 (Kołobrzeski - 149 individuals, Goleniowski - 368 individuals, Policki - 1,293 individuals) and only one such municipal poviat (Koszalin - 961 individuals) ${ }^{8}$. In 2010 an increase in the number of inhabitants was recorded for eight country poviats of Łódź voivodship, with the largest one occurring in the Eastern Łódź poviat (by 591 individuals) where numerous investments have recently been made in housing, both by private developers and in the scope of non-profit housing. The poviat showing a rise in its population figures that ranked second was the Zgierski poviat with an increase by 568 individuals.

The population of West Pomeranian voivodship accounts for $66.8 \%$ of that of Łódź voivodship. Łódź voivodship is inhabited by $6.6 \%$ of Poland's total population, while West Pomeranian voivodship - by only $4.4 \%$. The population decline improves rates of health care accessibility per the total number of inhabitants but emphasises the problem of the ageing of society. In 2010 in Poland there were as many as over $7.5 \mathrm{mn}$ individuals aged 60, which accounted for $19.7 \%$ of the whole population. In Łódź voivodship the population aged $60_{+}$ accounted for 7.4\%, while in West Pomeranian voivodship - for 4.3\%. Moreover, in 2010 only four poviats were characterised by a positive birth rate, with the highest one being recorded for the Bełchatowski poviat (3.1), the Skierniewicki poviat (2.3) ranking second, the Zduńskowolski (1) and Opoczyński poviats (0.9). The decline in the birth rate decreased in Łódź (-4.9) and the Poddębicki poviat $(-1.6)$, while it increased in the Kutnowski $(-4.3)$ and Lęczycki poviats $(-3.8)^{9}$. In 2010 the birth rate for West Pomeranian voivodship was $0.5^{10}$.

In a majority of poviats characterised by an increase in their populations, i.e. such where individuals settle to enjoy better access to the labour market, there is an unemployment rate lower than a mean voivodship rate (compare Figure 4).

The registered unemployment rate in eight country poviats and all municipal ones is lower than that rate for the whole Łódź voivodship. The situation is much worse in the poviats 


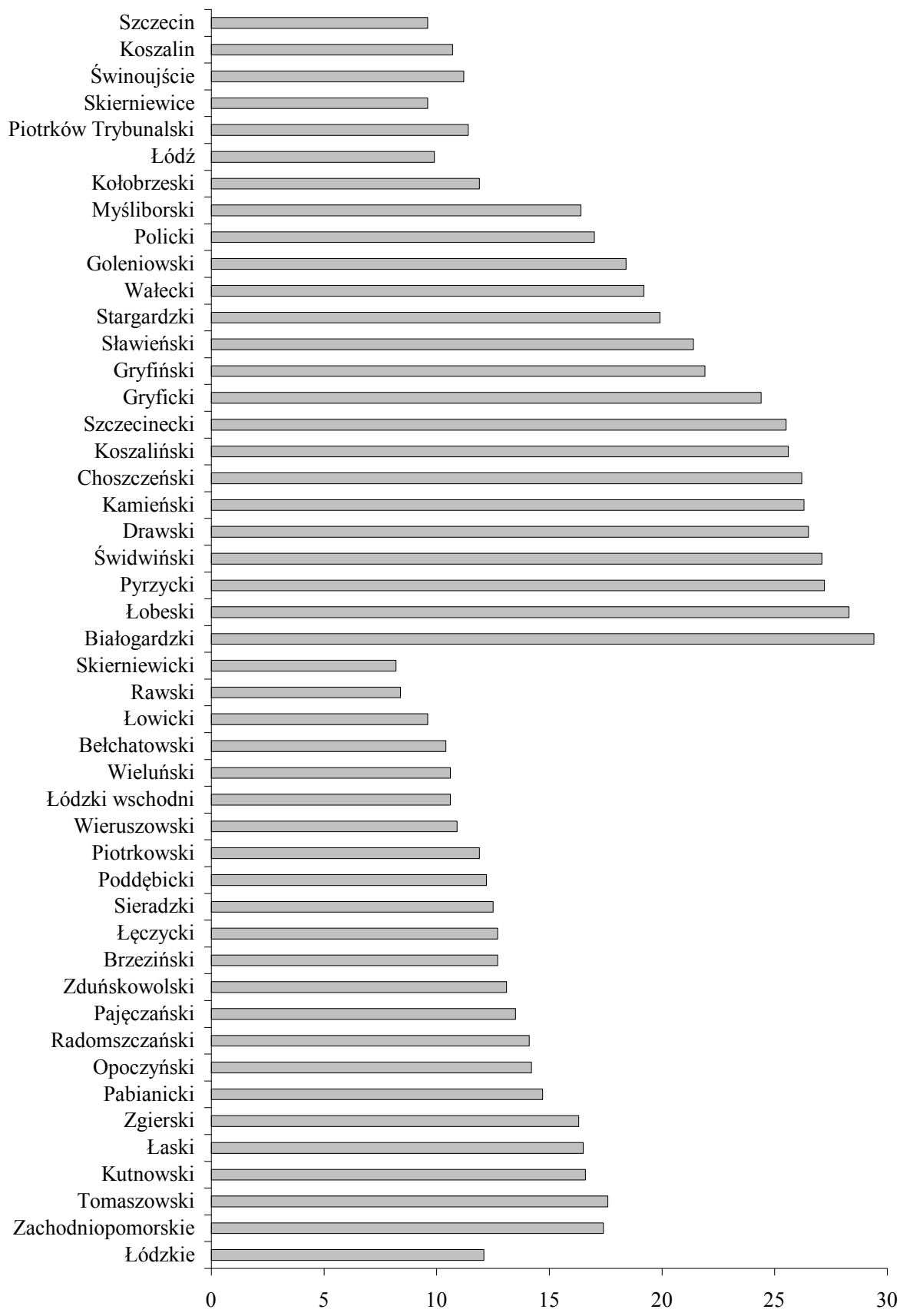

Fig. 4. Registered unemployment rate in the poviats of Łódź and West Pomeranian voivodships (31 December 2010)

Source: Central Statistical Office. 
of West Pomeranian voivodship, where only three country poviats and all municipal ones are characterised by an unemployment rate lower than the voivodship mean.

\section{Taxonomic Analysis}

Analysis consisting in the comparing of objects (statistical data of different denominations) characterised by a considerable number of variables (traits) most often applies taxonomic procedures that lead to determining the so called development measure. That measure is a synthetic value being the resultant of all variables describing objects of a studied set. That is why the measure can be used for the linear arrangement of elements of a given set. A list was created of the so called potential diagnostic variables taking into account statistical properties of selected traits. The studied multitrait object will be the poviats of Łódź and West Pomeranian voivodships from 1999 to 2010 . They are characterised by a list of variables at the disposal that may describe the poviats, considering the functioning of the health care system, for the purpose of conducting the study. They are as follows:

$l L_{\mathrm{it}} \quad$ - number of physicians (per one thousand inhabitants),

$l S z_{\text {it }} \quad$ - number of hospitals (per one thousand inhabitants),

$l L_{\mathrm{it}} \quad$ - number of hospital beds (per 10 thousand inhabitants),

$l A m_{\mathrm{it}}$ - outpatient clinics (per one thousand inhabitants),

$l A_{\text {it }} \quad$ - pharmacies (per one thousand inhabitants),

$l Z n_{\mathrm{it}} \quad$ - infant mortality (per one thousand live births),

$l Z p_{\text {it }}$ - number of places at full-time social assistance facilities (per one thousand inhabitants),

$l M z_{\text {it }}$ - places at day nurseries and nursery departments (per one thousand inhabitants),

$w B p_{\text {it }}$ - budgetary expenditures of the poviats on health care (in thousands PLN per one thousand inhabitants);

the $i t$ subscript of a variable is the value of a given variable in an $i$ poviat in a $t$ year.

The starting point for the construction of synthetic variables is an observation matrix:

$$
X=\left[\begin{array}{ccccc}
x_{11} & x_{12} & \ldots \ldots \ldots & x_{1 n} \\
x_{21} & x_{22} & \ldots \ldots \ldots & x_{2 n} \\
: & : & : & \ldots \ldots \ldots & : \\
: & : & : & \ldots \ldots \ldots & : \\
x_{n 1} & x_{n 2} & \ldots \ldots \ldots & x_{m n}
\end{array}\right]
$$

where $x_{i t}$ is the value of an $i$ diagnostic variable $(i=1, \ldots, m)$ in a period $(t=1, \ldots, n)$. 


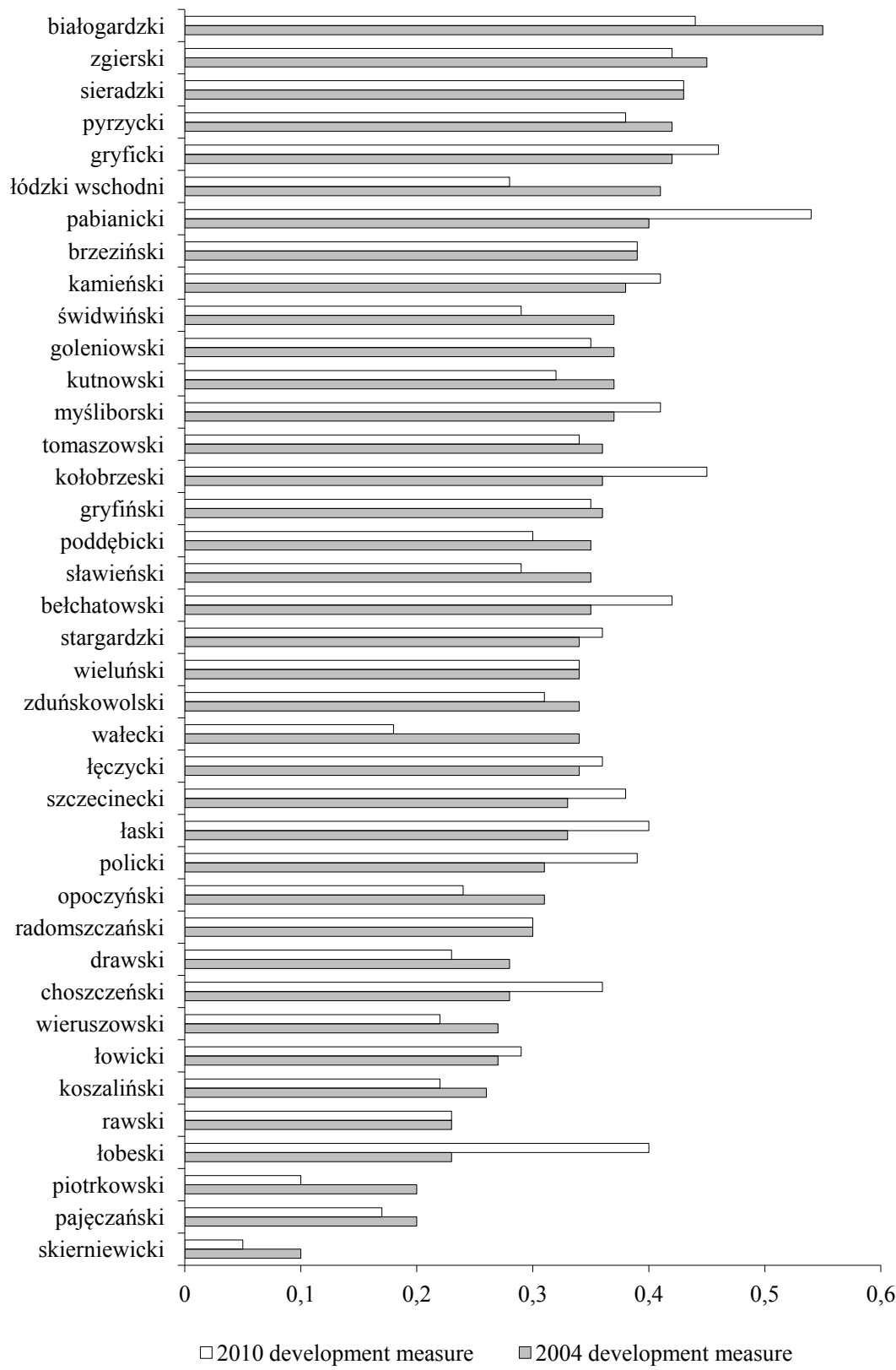

Fig. 5. Development measure of the country poviats of Łódź and West Pomeranian voivodships in 2004 and 2010

Source: own calculations. 
The objects are the poviats of Łódź and West Pomeranian voivodships. Diagnostic variables have different denominations and different variability ranges, which prevents their direct comparison. Thus, they were made comparable by means of standardisation ${ }^{11}$.

$$
\left.x_{i j} \cdot=\frac{x_{i j}-\bar{x}_{j}}{s_{j}}, \quad i=1, \ldots, n ; j=1, \ldots, p\right)
$$

where: $x_{j t}$ is the value of an $i$ diagnostic variable, $\bar{x}_{j}$ - the mean value of a variable, and $s_{j}-$ the standard deviation.

The development pattern method was used to study the health care condition in the poviats in 2004, i.e. upon Poland's joining the EU, and in 2010. That measure is a synthetic value being the resultant of all variables describing objects of the studied set. For the purpose of comparison and clarity of graphic presentation, the poviats were sorted according to the development measure for 2004 (compare Figure 5).

In 2010 an increase in the development measure occurred in 20 country poviats, with the biggest one being recorded in the Łobeski poviat - by 0.17 and the Pabianicki poviat - by 0.16 . In the Świdwiński poviat - an increase by 0.15 , in the Piotrkowski and Zgierski poviats - an increase by 0.14 , in the Białogardzki, Kutnowski, and Sławieński poviats - by 0.13 , and in the Poddębicki and Skierniewicki poviats - an increase by 0.10. In nineteen poviats the development measure values were lower in 2004 than in 2010. The most substantial decline was recorded for the Wałecki poviat $(-0.17)$, the Eastern Łódź poviat $(-0.13)$, the Białogardzki poviat $(-0.11)$, and the Piotrkowski poviat $(-0.1)$. In the Świdwiński, Opoczyński, Sławieński, and Poddębicki poviats the difference ranged from -0.08 to -0.06 , while in the other 11 poviats differences below -0.06 were observed. That indicates the worsening of health care conditions in those poviats. The calculated development measure for towns with poviat rights shows lower health care development in 2010 only for Świnoujście, which suggests health care deterioration in that town. The measure indicates a very slight increase in the development $(+0.01)$ for the town of Szczecin poviat. Koszalin, Piotrków Tryb., and Skierniewice entered a positive development path. Łódź was characterised by the biggest increase (by 0.29 ) in the health care development measure (compare Figure 6). 


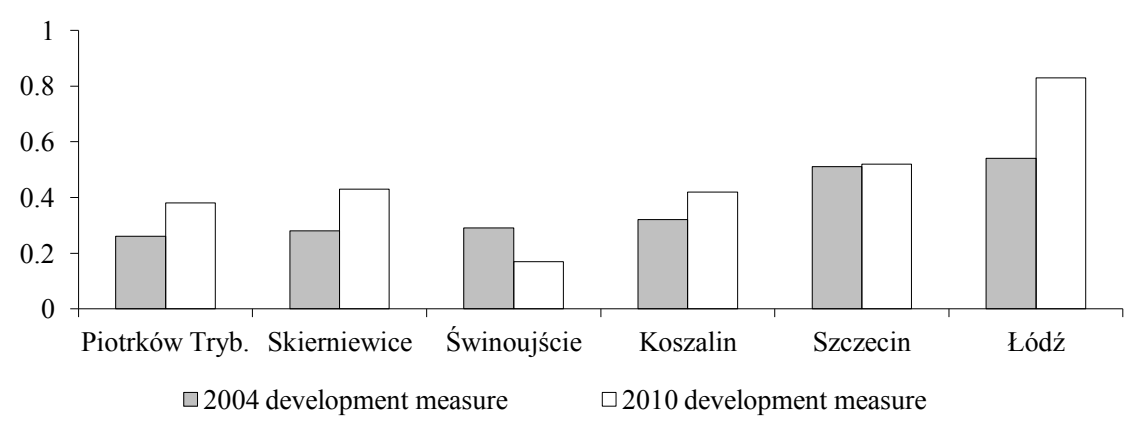

Fig. 6. Development measure of the municipal poviats of Łódź and West Pomeranian voivodships in 2004 and 2010

Source: own calculations.

Taxonomic analysis allows to classify and isolate clusters of poviats and towns with poviat rights similar in respect of selected variables that may be a measure of development and assessment of the functioning of the health care system ${ }^{12}$. The objective is to verify whether poviats of the two selected voivodships are characterised by the same efficiency of operations in the health care area and whether potential patients may expect identical health care accessibility conditions in those voivodships.

An agglomerative method was used to isolate groups of similar poviats. The poviats were divided into groups (called clusters) in such a way so that objects within one group were similar to one another and different from other groups. The minimum variance agglomerative method (Ward's method) was employed to obtain the lowest possible intra-cluster variance of traits characterising the poviats in the formed clusters for 2004 and 2010. Clustering results in the graphic form of a hierarchical tree plot (dendrogram) show similar poviats linked together in clusters.

The study presents only clustering for 2010, with a clustering diagram for 39 country poviats and 6 municipal ones. Three principal clusters of country poviats and two clusters of municipal poviats were obtained taking into account the development levels of their health care resources. In 201016 country poviats were linked together to form the I cluster, only 5 poviats - to make up the II cluster (Laski, Zgierski, Bełchatowski, Kołobrzeski, and Pabianicki), while the III cluster consisted of 18 poviats. Municipal poviats were aggregated in two clusters, the IV cluster being composed of four towns and the V one linking together Koszalin and Świnoujście (compare Figures 7 and 8). 


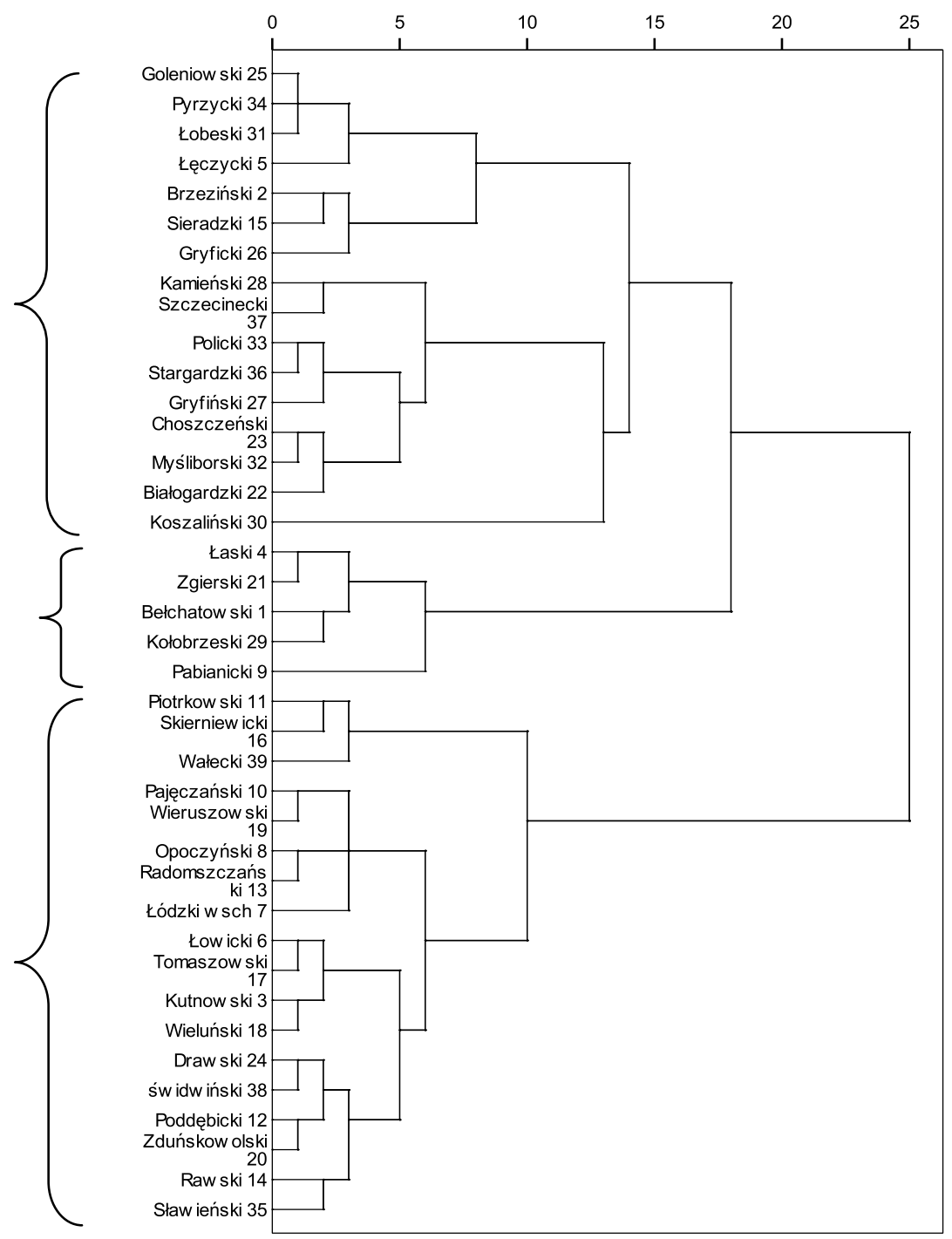

Fig. 7. Ward's method - clustering of country poviats for 2010 - linked clusters (distances drawn to scale)

Source: own work in the SPSS Program. 


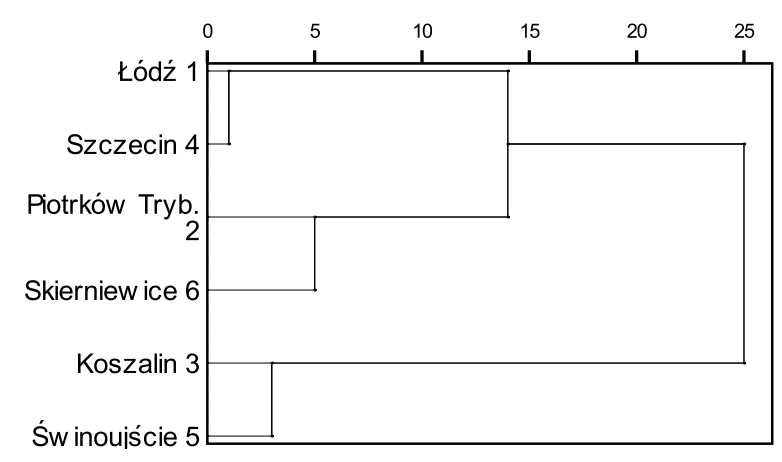

Fig. 8. Ward's method - clustering of municipal poviats for 2010 - linked clusters (distances drawn to scale)

Source: own work in the SPSS Program.

The analysis of the composition of specific clusters of country poviats indicates slight overlapping of spatial objects. Spatial diversification is much stronger than dynamic one. That results from the fact that there is a tendency within specific clusters to link together the same poviats in the two analysed years. The clustering of similar poviats will allow to detect differences in deviations of group effects in a panel model.

\section{Econometric Analysis}

Econometric models applied in the below-given analysis are estimated based on annual data for 45 poviats in the 1999-2010. The data are panel data, i.e. data combining cross-sectional and time dimensions and characterised by a large number of objects $N$ as compared with the number of periods $T$. Using such data requires to employ appropriate and specific estimation methods. The choice of the method depends on assumptions concerning the so called group effects. In the presented analysis the number of physicians per one thousand inhabitants (lLit) is subject to modelling. Values of that variable in specific poviats in the studied period indicate that levels of that variable in all studied groups - both its initial values for 1999 and its rate of growth - are different. The employment of physicians may be treated as a simplification of human resources in a poviat thanks to which the health condition of the region's population improves. In order to examine factors affecting physicians' employment structure in poviats, an FE panel model ${ }^{13}$ was applied with artificial variables (Fixed Effects Model) in the general form:

$$
y_{i t}=x_{i t}^{T} \beta+u_{i t}=x_{i t}^{T} \beta+\left(\alpha_{i}+\varepsilon_{i t}\right), \quad i=1, \ldots, N, \quad t=1, \ldots, T
$$


where the subscript $i$ assigns numbers to objects - poviats, while the subscript $t$ assigns numbers to years.

The $x_{i t}^{T}=\left[x_{1 i t}, \ldots, x_{K i t}\right]$ vector includes observations on explanatory variables, $\beta=\left[\beta_{1}, \ldots, \beta_{K}\right]^{T}$ is the vector of structural parameters, constant for $i$ and $t$, which means an assumption that the impact of each explanatory variable is the same for all objects and in all periods. Estimations of $\beta_{k}$ parameters express the mean effect of a change in a given $x_{k}$ variable for all objects, the mean effect being constant in time. The $u_{i t}$ random component in the formula is divided into two components: $\alpha_{i}$, which is constant in time and characteristic of an $i$ object - called the group effect, and a relevant $\varepsilon_{i t}$ random component presumed to meet the assumption of the classic Least Squares Method. The $\alpha_{i}$ group effect may be treated as a random variable or as a nonrandom one.

The RE model with the decomposition of the random component (Random Effect Model) in the general form:

$$
y_{i t}=\alpha+x_{i t}^{T} \beta+u_{i t}=\alpha+x_{i t}^{T} \beta+\left(\alpha_{i}+\varepsilon_{i t}\right), \quad i=1, \ldots, N, \quad t=1, \ldots, T
$$

for which it is assumed that the $\alpha_{i}$ group effects are random variables with the expected value of 0 and an identical variance for each $i$. The $\alpha_{i}$ effects and the $\varepsilon_{i t}$ component are independent of one another and of the $x_{k i t}$ variables. The $u_{i t}$ random component of the formula is divided into two components - the $\alpha_{i}$ group effect constant in time and the so called proper random component $\varepsilon_{i t}$ changing in time and for specific objects.

When creating the panel models, the econometric analysis assumed division into the groups of similar poviats formed through the 2010 clustering. That results from an intention to take into account the most recent trends concerning variables as factors reflecting the health care condition. Changes in the lLe variable in the poviats according to groups allowed to apply a linear form of the model with sequential elimination of insignificant variables ${ }^{14}$ (compare Tables 1 and 2).

Based on the results obtained from the model for the I group, the following conclusions can be reached: the response variable is considerably positively affected by the number of hospitals (per one thousand inhabitants) and, to a small extent, by the number of hospital beds (per 10 thousand inhabitants). A positive impact of the number of pharmacies (per one thousand inhabitants) occurred solely in that group of poviats, while the number of outpatient clinics (per one thousand inhabitants) exerted a slight negative influence. The comparison of model results for the II group with those for the III group indicates the stronger impact of the number of hospitals (per one thousand inhabitants) - an increase in the estimation of the relevant parameter 
Table 1. Results of estimations of panel models - country poviats

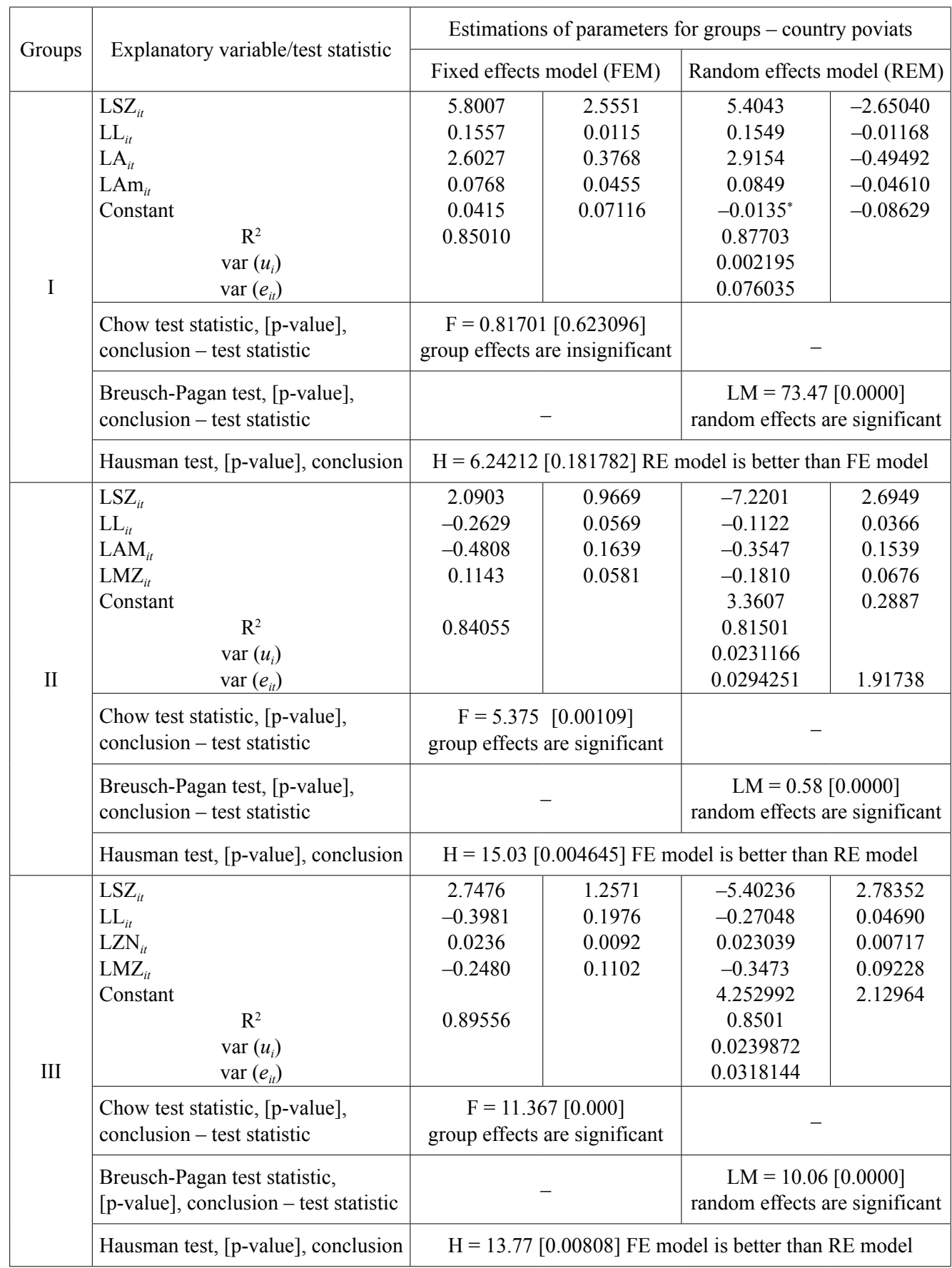

Source: own calculations in the Limdep Package, [ ${ }^{*}$ - variable significant at 0.1 level]. 
from 2.09 to 2.75 . The influence of the number of hospital beds (per 10 thousand inhabitants) was negative, being weaker in the III group of poviats. The negative impact of the number of outpatient clinics (per one thousand inhabitants) on the number of physicians (per one thousand inhabitants) occurred only in the II group. The value of the response variable in the III group was positively affected by infant mortality (per one thousand live births). On the other hand, a negative impact was observed for places at day nurseries and nursery departments (per one thousand inhabitants) in both the groups.

Table 2. Results of estimations of panel models - municipal poviats

\begin{tabular}{|c|c|c|c|c|c|}
\hline \multirow{2}{*}{ Groups } & \multirow{2}{*}{ Explanatory variable/test statistic } & \multicolumn{4}{|c|}{ Estimations of parameters for groups - municipal poviats } \\
\hline & & \multicolumn{2}{|c|}{ Fixed effects model (FEM) } & \multicolumn{2}{|c|}{ Random effects model (REM) } \\
\hline \multirow[t]{4}{*}{ IV } & \begin{tabular}{|l|}
$\mathrm{LL}_{i t}$ \\
$\mathrm{LA}_{i t}$ \\
$\mathrm{LZP}_{i t}$ \\
$\mathrm{LWBP}_{i t}$ \\
$\mathrm{LMZ}_{i t}$ \\
Constant \\
\\
\\
\end{tabular} & $\begin{array}{c}0.2201 \\
-2.1236 \\
0.0904^{*} \\
-0.0047^{*} \\
0.4948 \\
0.819834\end{array}$ & $\begin{array}{l}0.1091 \\
0.8835 \\
0.0092 \\
0.0046 \\
0.3500\end{array}$ & $\begin{array}{c}0.1910 \\
-1.7232 \\
-0.0741^{*} \\
-0.0081 \\
0.8461 \\
2.1946 \\
0.76208 \\
0.0160604 \\
0.184492 \\
\end{array}$ & $\begin{array}{l}0.0902 \\
0.7150 \\
0.0581 \\
0.0043 \\
0.1548 \\
0.7955\end{array}$ \\
\hline & $\begin{array}{l}\text { Chow test statistic, [p-value], } \\
\text { conclusion - test statistic }\end{array}$ & $\begin{array}{r}F=4.16 \\
\text { group effec }\end{array}$ & $\begin{array}{l}01184] \\
\text { significant }\end{array}$ & & \\
\hline & $\begin{array}{l}\text { Breusch-Pagan test statistic, } \\
\text { [p-value], conclusion - test statistic }\end{array}$ & & & $\begin{array}{r}\mathrm{LM}=0 . \\
\text { random effec }\end{array}$ & $\begin{array}{l}.0000] \\
\text { significant }\end{array}$ \\
\hline & Hausman test, [p-value], conclusion & $\mathrm{H}=7.78$ & 8941] RE m & odel is better th & E model \\
\hline \multirow{4}{*}{$\mathrm{V}$} & $\begin{array}{c} \\
\mathrm{R}^{2} \\
\operatorname{var}\left(u_{i}\right) \\
\operatorname{var}\left(e_{i t}\right) \\
\end{array}$ & $\begin{array}{c}45.1059 \\
0.3903 \\
0.9189 \\
0.984326\end{array}$ & $\begin{array}{l}6.2735 \\
0.0803 \\
0.2587\end{array}$ & $\begin{array}{c}40.1416 \\
0.2679 \\
0.7960 \\
-0.2348^{*} \\
0.9085977 \\
0.000650512 \\
0.00914201 \\
\end{array}$ & $\begin{array}{l}5.3921 \\
0.0146 \\
0.2462 \\
0.1362\end{array}$ \\
\hline & $\begin{array}{l}\text { Chow test statistic, [p-value], } \\
\text { conclusion - test statistic }\end{array}$ & $\begin{array}{r}F=2.42 \\
\text { group effect }\end{array}$ & $\begin{array}{l}\text { 13606] } \\
\text { nsignificant }\end{array}$ & & \\
\hline & $\begin{array}{l}\text { Breusch-Pagan test statistic, } \\
\text { [p-value], conclusion - test statistic }\end{array}$ & \multicolumn{2}{|c|}{-} & \multicolumn{2}{|c|}{$\begin{array}{l}\mathrm{LM}=1.05[0.0000] \\
\text { random effects are significant }\end{array}$} \\
\hline & Hausman test, [p-value], conclusion & \multicolumn{4}{|c|}{$\mathrm{H}=1.00[0.00808] \mathrm{FE}$ model is better than RE model } \\
\hline
\end{tabular}

Source: own calculations in the Limdep Package, [ ${ }^{*}$ - variable significant at 0.1 level]. 
An influence of the poviats' budgetary health care expenditures (in thousands PLN per one thousand inhabitants) occurred only in the IV group of municipal poviats. A positive impact on the response variable was observed through the number of hospital beds (per 10 thousand inhabitants) and places at day nurseries and nursery departments (per one thousand inhabitants). In the $\mathrm{V}$ group of municipal poviats, the strongest impact on the employment of physicians was recorded for the number of hospitals (per one thousand inhabitants), and a considerably weaker one for the number of outpatient clinics (per one thousand inhabitants) and the number of hospital beds (per 10 thousand inhabitants).

Statistical tests whose results are shown in Tables 1 and 2 are specific to panel models. The Chow test (F test) verifies whether an FE model is more correct than a model that does not consider group effects, while the Breusch-Pagan test compares an RE model with a model with no group effects. The results of both the tests unambiguously indicate that there are nonmeasurable factors specific to the poviats. The Hausman test determines which of the models: FE or RE is more statistically correct. The empirical value of the statistic of that test suggests that the model with random effects is more statistically correct than the model with non-random effects, which means that the non-measurable group effects do not correlate with the explanatory variables of the model.

Despite the performed clustering of similar poviats, the panel models allowed to detect diversity in group effects' deviations in the II, IV, and III groups, when assessing the impact on the employment of physicians (compare Figures 9 and 10).

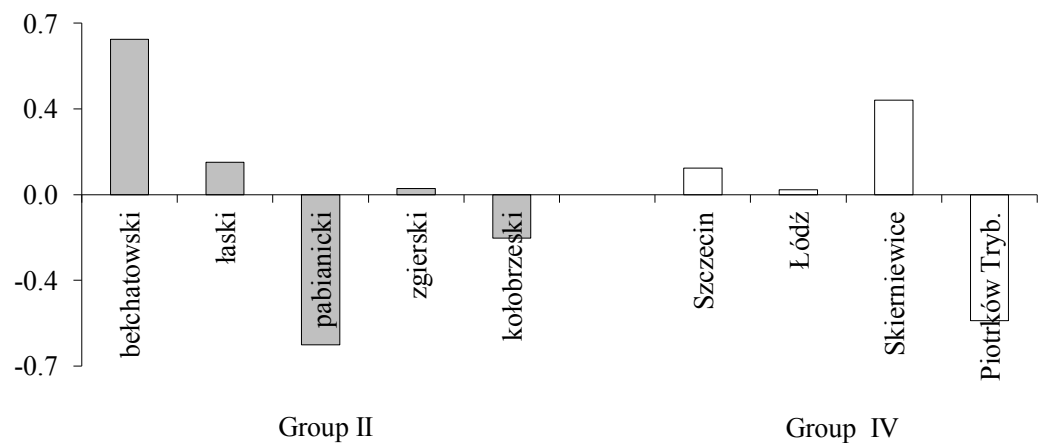

Fig. 9. Deviations of group effects from the mean - II and IV group poviats Source: own work. 
In the II group of poviats the Pabianicki and Zgierski poviats do not have considerable influence on the number of physicians per one thousand inhabitants in the studied period as the effects have the lowest values. That number is the most strongly affected by the Bełchatowski poviat. In that poviat there was the largest increase in the dynamics of the budgetary incomes of gminas in 2010. The Kołobrzeski poviat may be considered residual in that group as the group effects are close to the mean for the II group. Łódź is the residual town for the IV group of municipal poviats. The rate is most strongly affected by the Skierniewice municipal poviat and, to a much lesser extent, by Szczecin. In the studied period the least influence on the number of physicians per one thousand inhabitants was recorded in Piotrków Tryb. The assessment of group effects for the III group of country poviats allows to infer that the least influence is exerted by the Piotrkowski, Skierniewicki, and Wieruszowski poviats, while the biggest one - by the Wieluński and Rawski poviats.

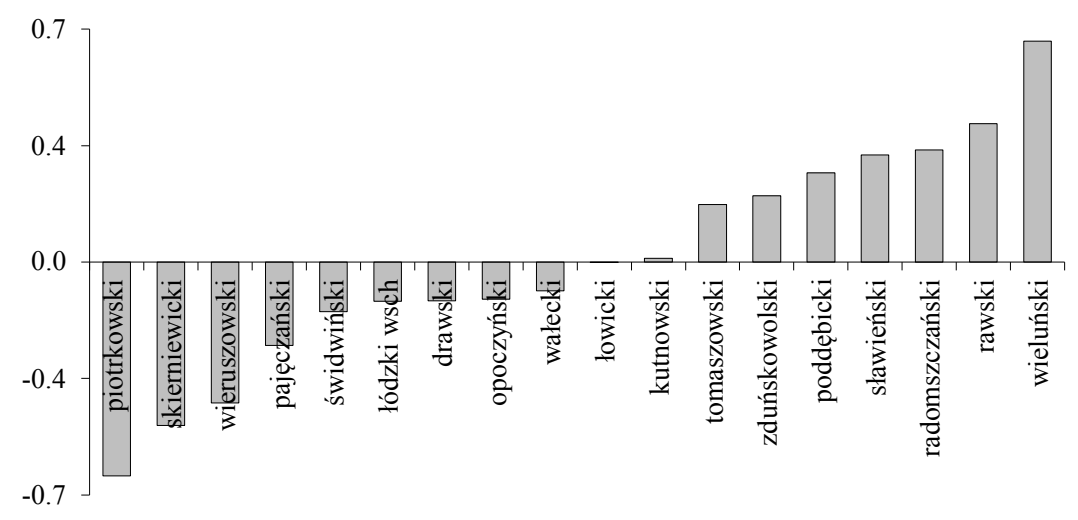

Fig. 10. Deviations of group effects from the mean - III group poviats

Source: own work.

The occurring diversification, as compared with the mean effects, probably results from transformation in the poviats and overlapping changes over the period of twelve years as well as health care reorganisation. The non-measurable factors specific to particular poviats are of a different nature for the I group of country poviats and the IV group of municipal ones for which models with random effects proved to be better. The set of explanatory variables turned out to be slightly different in the models describing changes in the number of physicians (per one thousand inhabitants) in all the poviat groups. The variables were selected from a pool of all variables considered in the specification serving to assess the health care situation of the regions. 


\section{Conclusions}

The presented study described the functioning of health care in the poviats of Łódź and West Pomeranian voivodships based on available statistical data. The development pattern method was employed to assess the resources and infrastructure of the health care system in those poviats. The clustering of similar poviats in the region used the cluster analysis method. Three principal clusters of country poviats and two clusters of municipal ones were isolated as the voivodships' centres. The clusters served to create panel models that allowed to determine group and random effects. Thanks to the application of panel models, it was possible to find out that physicians' employment level is affected, in the II, III, and V groups as well as in the I and IV groups, by non-measurable factors typical of the poviats. However, the nature of those group effects differs: in the II, III, and V groups they do not correlate with explanatory variables, while in the I and IV groups such correlation is observed.

Econometric analysis allowed to detect factors characterising the poviats in a significant way and affecting human capital, i.e. physicians working in the studied groups of poviats. Common factors were indicated that affected the number of physicians in the poviats, although their impact proved to differ in its strength. Inter-voivodship differences in Poland result from long-standing diversities in processes that took place in specific areas of Poland and translate into the constant lack of cohesion, which is clearly seen in health care despite expectations of uniformity. The quality of the operation of public facilities, with an increasing role of social capital, becomes a vital component and source of a region's competitive edge.

\section{Notes}

1 Ekonomiczno-organizacyjne uwarunkowania rozwoju regionu... (2004), p. 252.

2 Zróżnicowanie rozwoju polskich regionów... (2008), pp. 142-144.

3 Noworól et al. (2003), p. 162; Rozpędowska-Matraszek (2011).

4 Batóg (2006), pp. 52-53.

5 Wzrost gospodarczy a bezrobocie... (2008), pp. 216-217.

6 Błędowski et al. (2009), p. 7.

7 Szczech-Pietkiewicz (2008), p. 10.

8 Rocznik Statystyczny Województwa Zachodniopomorskiego (2010), p. 212.

9 Ludność, ruch naturalny i migracje... (2011), pp. 36-42.

${ }_{10}$ Województwo zachodniopomorskie w liczbach... (2011), p. 5.

11 Jajuga (1998), p. 29.

12 Rozpędowska-Matraszek (2010), pp. 145-156.

${ }_{13}$ Danska-Borsiak (2011), pp. 40-54. 
${ }^{14}$ Estimation methods for FE and RE models are based, depending on the model type, on the classic Least Squares Method or the generalised Least Squares Method as there is no delayed response variable among explanatory variables. The presented methodology and special statistical tests, verifying whether the isolation of group effects has been justified, allow to select an FE or RE model.

\section{References}

Batóg, J. (2006). Próba klasyfikacji czynników wzrostu gospodarczego. In: Metody ilościowe w ekonomii, J. Hozer (Ed.), Szczecin: Zeszyty Naukowe Uniwersytetu Szczecińskiego nr 450, Prace Katedry Ekonometrii i Statystyki nr 17.

Błędowski, P. et al. (2009). Stan i prognoza rozwoju województwa zachodniopomorskiego, Projekt „Regionalny Barometr Gospodarki”, Województwo zachodniopomorskie. Szczecin: Wojewódzki Urząd Pracy.

Dańska-Borsiak, B. (2011). Dynamiczne modele panelowe w badaniach ekonomicznych. Łódź: Wydawnictwo Uniwersytetu Lódzkiego.

Jajuga, K. (1998). Ekonometria. Metody i analiza problemów ekonomicznych. Wrocław: Wydawnictwo Akademii Ekonomicznej.

Zróżnicowanie rozwoju polskich regionów. Elementy teorii i próba diagnozy (2008). E. Kwiatkowski (Ed.), Łódź: Wydawnictwo Uniwersytetu Łódzkiego.

Noworól, A. et al. (2003). Podstawy zarządzania w administracji publicznej. Szczecin: Wyd. WSAP w Szczecinie.

Wzrost gospodarczy a bezrobocie i nierówności w podziale dochodu (2008). W. Pacho, M. Garbicz (Ed.). Warszawa: Szkoła Główna Handlowa.

Rozpędowska-Matraszek, D. (2010). Funkcjonowanie opieki zdrowotnej w woj. tódzkim-analiza regionalna. In: Ekonomia i Zarzadzanie, Colin F. Hales (Ed.), Nauka dla gospodarki Zeszyty Naukowe 1/2010 Uniwersytetu Rzeszowskiego. Rzeszów: Wyd. Uniwersytet Rzeszowski.

Rozpędowska-Matraszek, D. (2011). Grupy powiatów podobnych na przykładzie opieki zdrowotnej Regionu Centralnego. Analiza z wykorzystaniem modeli panelowych. Rzeszów: Uniwersytet Rzeszowski.

Ekonomiczno-organizacyjne uwarunkowania rozwoju regionu - teoria i praktyka. (2004).

D. Stawasz (Ed.). Łódź: Wydawnictwo Uniwersytetu Łódzkiego .

Szczech-Pietkiewicz, E. (2008). Regulacje i rekomendacje ponadnarodowe w zakresie polityki przestrzennej, In: Wyzwania dla polskiej polityki przestrzennej (materiały konferencyjne), Warszawa: Biuro Analiz Sejmowych, Wyd. Kancelaria Sejmu. 
Ludność, ruch naturalny i migracje $w$ województwie łódzkim w 2010 r. (2011). Informacje i opracowania statystyczne. Urząd Statystyczny w Łodzi. Warszawa: Zakład Wydawnictw Statystycznych.

Rocznik Statystyczny Województwa Zachodniopomorskiego (2010). Urząd Statystyczny w Szczecinie. Warszawa: Zakład Wydawnictw Statystycznych.

Województwo zachodniopomorskie w liczbach 2011 (2011). Szczecin: Urząd Statystyczny w Szczecinie.

www.stat.gov.pl/gus; stm (28.07.2011).

www.regiony.poland.gov.pl, stm (28.07.2011). 